SECTION 32. Jurisprudence.

\author{
Anisimov Alexey Pavlovich, \\ Doctor of Law, Professor \\ Professor of the Department of Civil Law \\ Volgograd Institute of Business, Russia \\ e-mail: anisimovap@mail.ru
}

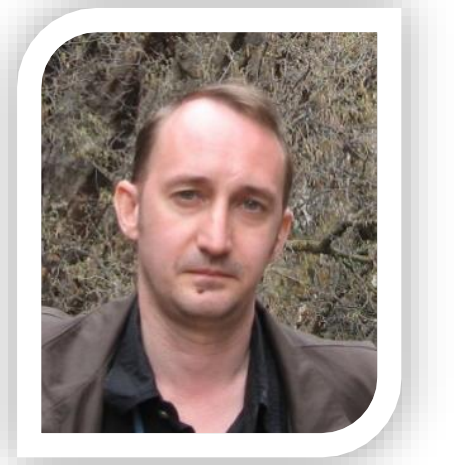

\title{
ENSURING FOOD SECURITY RUSSIA: PROBLEMS AND SOLUTIONS
}

Abstract: The article examines the legal category of "ensuring food security." The reasons of the absence of its solutions at the international and national level. Among the problems of ensuring global food security are considered global financial and economic crisis as well as climate change. As national (Russian) problems mentioned WTO accession, corruption, illegal migration and others.

Key words: food security, food, agricultural producers; hunger; import; industry

\section{ОБЕСПЕЧЕНИЕ ПРОДОВОЛЬСТВЕННОЙ БЕЗОПАСНОСТИ РОССИИ: ПРОБЛЕМЫ И ПУТИ ИХ РЕШЕНИЯ}

Аннотация: В статье рассматривается правовая категория «обеспечение продовольственной безопасности». Выявляются причины отсутствия ее решения на международном и национальном уровне. В числе глобальных проблем обеспечения продовольственной безопасности рассматриваются мировой финансовый $u$ экономический кризис, а также изменения климата. В качестве национальных (российских) проблем упоминаются вступление в ВТО, коррупщия, незаконная миграция и ряд других.

Ключевые слова: продовольственная безопасность; продукты питания; сельскохозяйственные товаропроизводители; голод; импорт; промыиленность

Проблема обеспечения населения продовольствием не является чем-то особенным, присущим только России или иным странам СНГ. Она существовала всегда, сохраняется в настоящее время и носит общемировой характер.

Согласно одной из существующих официальных дефиниций, изложенной в Решении Межгосударственного совета Евразийского экономического сообщества от 11 декабря 2009 г. № 464 «О Концепции продовольственной безопасности Евразийского экономического сообщества», продовольственная безопасность государства состояние экономики государства, при котором за счет собственного производства обеспечивается продовольственная независимость страны и гарантируется физическая и экономическая доступность основных видов продовольствия и чистой питьевой воды для всего населения в количестве и качестве, необходимых для активной и здоровой жизни, обеспечения демографического роста.

Впервые мировое сообщество обратило внимание на проблему обеспечения продовольственной безопасности в глобальном и национальном масштабе в середине 70 -х годов XX века, чему способствовал зерновой кризис начала 70-х гг. XX века. Это обусловило принятие ряда международных актов, в числе которых следует, в первую очередь, выделить Всеобщую декларацию о ликвидации голода и недоедания, одобренную резолюцией 3348 (XXIX) Генеральной Ассамблеи ООН от 17 декабря 1974г.

В Декларации Всемирного саммита по продовольственной безопасности (Рим, 16 ноября 2009 г.) отмечалось, что в настоящее время число людей, страдающих от 
голода и нищеты, превысило 1 млрд. человек. Это представляет собой неприемлемое явление, затрагивающее жизнь, средства к существованию и достоинство одной шестой части населения мира. Какие же основные угрозы выделяются на глобальном уровне?

1) продовольственный кризис тесно связан с финансовым и экономическим кризисами. Согласно экспертным оценкам, для того, чтобы прокормить население мира, численность которого превысит в 2050 году 9 млрд. человек, потребуется увеличить к этому году объем производства сельскохозяйственной продукции на 70 процентов;

2) новые серьезные угрозы для продовольственной безопасности возникают в связи с изменением климата. Ожидаемые последствия такого изменения особенно опасны для мелких сельских товаропроизводителей в развивающихся странах, а также иных уязвимых категорий населения. Суть данной проблемы заключается в том, что глобальное потепление может привести не только к изменению конфигурации обитаемой суши (из-за поднятия уровня мирового океана), но и изменению традиционных мест ведения сельского хозяйства. Не исключено, что в результате таких процессов в России растают районы вечной мерзлоты (и сделаются пригодными для сельского хозяйства), в то время как современные сельскохозяйственные районы Средиземноморья превратятся в страны с жарким пустынным климатом.

Нельзя сказать, что эти проблемы не волнуют научное сообщество. Во многих зарубежных исследованиях делаются прогнозы антропогенного воздействия на изменения климата и изучаются национальные усилия по планированию его преодоления в ряде стран мира (например, США, Великобритании и Китае), [1, с. 359382] а также социальные последствия изменения климата [2, с. 41].

Большую роль в мобилизации усилий международного сообщества может сыграть принятие Конвенции о сотрудничестве в области обеспечения международной продовольственной безопасности. В ней следует дать определение международной продовольственной безопасности и правовые основы сотрудничества государств в исследуемой сфере - уважение права человека на питание, обеспечение безопасности продуктов питания для здоровья человека, оказание продовольственной помощи [3,c.13].

Как отмечал N.A. Fromherz, необходимо различать категории «продовольственная безопасность» и «продовольственная независимость». Концепция продовольственного суверенитета подразумевает различия между, во-первых, нациями, имеющими возможность кормить свой народ любыми средствами, и, во-вторых, нациями, имеющими возможность кормить свой народ за счет собственных ресурсов. Страна, которая может накормить собственный народ, при любом внешнем воздействии будет иметь достаточную устойчивость, чтобы действовать с максимальной независимостью. Государство, которое не может удовлетворить элементарные потребности своего народа - в физической безопасности, основных товарах и услугах, питании - подлежит запугиванию и принуждению из-за рубежа. Некоторые страны уже страдают от отсутствия продовольственной безопасности и суверенитета, например, Мадагаскар [4, с. 67].

Продовольственные проблемы приобретают особую актуальность на национальном уровне, где общемировые тенденции накладываются на национальную специфику. Так, в России с 2000 года стоимость ввезенного продовольствия ежегодно увеличивается на $30 \%$ в год и в 2011 г. объем импорта продовольственных товаров и сельскохозяйственного сырья для их производства составил 42,5 млрд. дол. США против 35,2 млрд. долл. в 2008 г. и 36,4 млрд. долл. в 2010 г. Аграрный импорт страны сопоставим по стоимости с экспортом российского газа в Западную Европу. Однако страна, обладающая значительной зависимостью от импорта продовольствия, не может являться в полной мере практически экономически и политически независимой, и при возникновении международных конфликтов подобная зависимость становится 
угрожающей для национальной безопасности Российского государства [5, с. 36-37].

Каковы же основные проблемы обеспечения в России продовольственной безопасности, каково их содержание и причины появления?

1) сокращение площади обрабатываемых сельскохозяйственных угодий, ухудшение состояния земель, ускоренное выбывание из использования сельскохозяйственной техники, до $70 \%$ которой превысило нормативный срок эксплуатации. В совокупности со снижением инвестиционной привлекательности страны, это является препятствием для их обновления, а также социального и демографического развития села.

2) установление контроля со стороны ряда зарубежных компаний над отдельными отраслями сельскохозяйственной промышленности, с одной стороны, и увеличение ввоза в страну незаконных мигрантов для работы в сельском хозяйстве, с другой. Последнее обстоятельство влечет дальнейшую маргинализацию сельского населения.

3) обеспечение экологической безопасности пищевых продуктов [6, с. 568-572]. Одним из аспектов этой проблемы является ввоз в Россию и выращивание на ее территории продукции, содержащей ГМО. Как отмечала Е.А. Жемчужнова, действующее российское законодательство в области генно-инженерной деятельности «не в состоянии обеспечить безопасность человека, его будущих поколений и окружающей среды от негативного воздействия генетически модифицированных организмов в долгосрочной перспективе. Абсолютная безопасность генетически модифицированных продуктов питания для здоровья человека не доказана, и использование таких продуктов несет в себе колоссальные риски для человека» [7,c.123].

4) вступление России в ВТО приведет к дальнейшему росту импорта зарубежной сельскохозяйственной продукции, снижению государственной поддержки и разорению фермеров и иных российских сельскохозяйственных товаропроизводителей.

5) коррумпированность и неэффективность государственного управления сельским хозяйством. Под последним в России обычно понимается «целенаправленная деятельность государства и его органов (всех трех ветвей власти) по осуществлению современной аграрной политики с целью обеспечения продовольственной безопасности и конкурентоспособности российского товаропроизводителя на мировом аграрном рынке». [8, с. 42]. Неэффективность государственного управления и государственной аграрной политики можно наблюдать как на бытовом уровне, покупая в магазине не тамбовскую, а израильскую картошку, так и на доктринальном уровне, обобщая сведения, размещенные в открытых источниках. Приведу ряд примеров только одного региона.

Так, резкий рост в начале 2014 года в Волгоградской области цены за литр молока объясняется несвоевременностью выплат дотаций фермерам в условиях ощутимого (в три раза) роста платы за электроэнергию, солярку и т.д. В этих условиях многие фермеры были вынуждены прекратить заниматься животноводством [9].

К этому следует добавить низкие закупочные цены на сельскохозяйственную продукцию, закрытие самостоятельного доступа сельских товаропроизводителей на рынки сбыта, низкие закупочные цены со стороны посредников.

Сюда же добавляется и непродуманное и ничем не обоснованное резкое увеличение кадастровой стоимости сельскохозяйственных угодий. Так, если до 1 января 2014 года гектар земли в Котовском районе Волгоградской области стоил в среднем 858 рублей, то теперь его кадастровая стоимость увеличилась от 20 до 25 раз! Соответственно, многократно повысился и налог на землю, поступающий в местный бюджет, что грозит разорением не только сельскохозяйственным товаропроизводителям, но и ударит по жителям сельских поселений, которые сдают свои земельные доли в аренду [10]. 
На фоне увеличения расходов областного бюджета на содержание чиновников, в т.ч. их саморекламу в средствах массовой информации, расходы бюджета на поддержку аграрного сектора продолжают снижаться. Согласно ст.12 Закона Волгоградской области от 20 декабря 2012 года «Об областном бюджете на 2013 год и на плановый период 2014 и 2015 годов», субсидии на государственную поддержку АПК составляли 1672617,0 тыс. рублей. Согласно ст.12 Закона Волгоградской области от 5 декабря 2013 года «Об областном бюджете на 2014 год и на плановый период 2015 и 2016 годов», субсидии на государственную поддержку в сфере АПК в 2014 году снизились до 1113290,3 тыс. рублей, а в 2015 году - будут снижены до 1019290,3 тыс. рублей [11].

Между тем, игнорирование проблемы обеспечения продовольственной безопасности скоро может привести к прохождению «точки не возврата».

Продовольственная безопасность страны - это одна из главных гарантий закрепленного Конституцией России права на жизнь, необходимое условие государственного суверенитета, гарантия стабильности и социального мира. К сожалению, следует признать, что органы государственной власти России, вместо решения этой по-настоящему важной проблемы, постоянно пытаются акцентировать внимание общества на третьестепенных проблемах, типа пропаганды гомосексуализма в интернете или обсуждения путей принудительного насаждения патриотизма. Между тем, невозможность обеспечения продовольственной безопасности делает страну очень уязвимой.

\section{Список использованной литературы}

1) Farber D.A. The Challenge of Climate Change Adaptation: Learning from National Planning Efforts in Britain, China, and the USA // Journal of Environmental Law. 2011. Vol. 23:3. P. 359-382.

2) Farber D.A. Pollution Markets and Social Equity: Analyzing the Fairness of Cap and Trade // Ecology Law Quarterly. 2012. Vol. 39. P. 1-56.

3) Валетова Ю.А. Международно-правовое обеспечение продовольственной безопасности: автореф. дис. ... канд. юрид. наук. М., 2013. 29 с.

4) Fromherz N.A. The Case for a Global Treaty on Soil Conservation, Sustainable Farming, and the Preservation of Agrarian Culture // Ecology Law Quarterly. 2012. Vol. 39. P. 57-121.

5) Быстров Г.Е. Право российских граждан на полноценное питание и правовое обеспечение продовольственной безопасности России // Новая правовая мысль. 2013. № 2. C.36-40.

6) Чикильдина А.Ю. Эколого-правовые исследования в сфере обеспечения безопасности пищевых продуктов// Научные труды. Российская академия юридических наук. Выпуск 11. Т.2. М.: Издательская группа «Юрист», 2011. С. 568-572.

7) Жемчужнова Е.А. Правовое регулирование использования ГМО на территории Российской Федерации // Новая правовая мысль. 2013. № 2. С.123-128.

8) Файзуллин Г.Г., Салахова Г.Г. Некоторые теоретические аспекты государственного управления сельским хозяйством в постсоветской России // Новая правовая мысль. 2005. № 1. С.38-42.

9) Фермеры: Рост цен на молоко в магазинах Волгограда - результат политики губернатора Боженова [Электронный ресурс]. URL: http://v102.ru/econom/43233.html (дата обращения 13.02.2014)

10) Фермеры Волгоградской области - президенту: «Повышение в регионе кадастровых ставок за сельхозугодья - это удар под дых!» [Электронный ресурс]. URL: http://v102.ru/econom/43032.html (дата обращения 13.02.2014).

11) Открытый бюджет Волгоградской области. [Электронный ресурс]. URL: http://budget.volganet.ru/budget/law/ (дата обращения 13.02.2014). 